Creative Commons User License: CC BY-NC-ND

Abstracted by: EBSCOhost, Electronic Journals Service (EJS), Google Scholar, Journal Seek, Scientific Commons,

Food and Agricultural Organization (FAO), CABI and Scopus

http://eoi.citefactor.org/10.11226/v24i3
Journal of Agricultural Extension

Vol. 24 (3) July, 2020

ISSN(e): 24086851; ISSN(Print); 1119944X

http://journal.aesonnigeria.org

http://www.ajol.info/index.php/jae

Email: editorinchief@aesonnigeria.org

\title{
Impact of Training of Small-Scale Dairy Farmers on Milk Production and Income in Ethiopia \\ https://dx.doi.org/10.4314/jae.v24i3.1
}

\section{Seble, Wongel Getachew}

Holeta Agricultural Research Center, Ethiopia

E-mail: bekele.seblewongel@gmail.com

+251-116-454452

\section{Satoko, Kubota}

Department of Agro-environmental Science, Division of Agricultural Economics. Obihiro University of Agriculture and Veterinary Medicine, Japan

E-mail : skubota@obihiro.ac.jp

+81-155-49-5439

\section{Toshihisa, Kanayama}

Department of Agro-environmental Science, Division of Agricultural Economics. Obihiro University of Agriculture and Veterinary Medicine, Japan

Email: kanayama@obihiro.ac.jp

$+81-155-49-5424$

\section{Tiana Navalona Randrianantoandro}

Mention Agro-management, Ecole Supérieure des Sciences Agronomiques, Université

d'Antananarivo, Madagascar

E-mail : trandrianantoandro@yahoo.fr

+ 261-34- 27- 80134

\section{Hiroichi Kono}

Department of Agro-environmental Science, Division of Agricultural Economics. Obihiro University of Agriculture and Veterinary Medicine, Japan

E-mail : kono@obihiro.ac.jp

$+81-155-49-5452$

\section{Abstract}

This paper examined dairy husbandry training impact on milk production and milk income under smallholder farmers' management condition. A cross-sectional survey was conducted in two districts in Ethiopia and the data was collected from a total of 180 smallholder dairy farmers (60 of the participants were trained on dairy husbandry practices). Propensity Score Matching (PSM) technique was employed to construct suitable comparable group and to calculate the average treatment effect on the treated sample. The average treatment effect on the treated shows that dairy husbandry training increased milk production, volume of milk processed and milk income by about $21.7 \%, 56.5 \%$ and $22.5 \%$ respectively. This study confirms that training on dairy husbandry plays great role to bring change in dairy technology adoption which further enhance milk production and milk income under smallholder farmers' management condition. 
Creative Commons User License: CC BY-NC-ND

Abstracted by: EBSCOhost, Electronic Journals Service (EJS), Google Scholar, Journal Seek, Scientific Commons,

Food and Agricultural Organization (FAO), CABI and Scopus
Journal of Agricultural Extension

Vol. 24 (3) July, 2020

ISSN(e): 24086851; ISSN(Print); 1119944X

http://journal.aesonnigeria.org

http://www.ajol.info/index.php/jae

Email: editorinchief@aesonnigeria.org

Keywords: milk income; milk production; Ethiopia; propensity score matching; smallholder dairy farmers, training

\section{Introduction}

Promoting sustainable agriculture and rural development plays a crucial role to satisfy the ever increasing demand of growing population in developing countries (United Nations, 2015). This creates an opportunity for smallholder farmers to benefit from the growing demand for dairy products through income and employment generation Dessisa, Roesel, Makita, Teklu, Zewde, and Grace (2015). However, they lack the required technological, organizational as well as institutional capacities (Guadu and Abebaw, 2016). Dissemination of improved husbandry practice through farmers training is an important strategy for enhancing competence among the target audience and thus increasing adoption (Luyombya, 2014). For that purpose, many foreign aid agencies fund large-scale agricultural training for farmers in developing countries, but little rigorous research has been conducted on whether these programs are effective (Wordofa and Sassi, 2018).

Studies in many developing countries indicates that training on dairy farming had positive and highly significant relationship with the adoption of improved dairy husbandry practices (Dehinenet, Mekonnen, Kidoido, Ashenafi and Guerne 2014; Samuel,Misganaw, Efrem, Beza and Addisu, 2016), increase in yield (Kazanga, 2012) and technical efficiency (Ullah, 2016). Sharma, Singh, and Keshava (2014) reported that training programs has a significant impact in uptake of new technologies, help in achieving sustainable production and in turn will increase the income and employment in the rural areas. On the other hand, a study by Sajeev, Singha and Venkatasubramanian (2012) confirms the importance of training, which can contribute to enhancement of farmers' skills in farming works.

Most of the studies conducted in developing countries addressed the impact of training on intermediate outcomes such as adoption rate of diary technologies, agricultural productivity, technical efficiency and attitudinal change. In addition to this, the content of training provided, their aim and the type of breed used was quite variable from country to country. Thus, there is no clear information available that indicate the exact impact of dairy husbandry training on milk income. This study assessed the impact of dairy husbandry training on milk production and income.

\section{Methodology}

This study was conducted in Adaberga and Cheliya district of west Showa zone, Ethiopia (geographic coordinates: $9.1515^{\circ} \mathrm{N}, 37.8088^{\circ} \mathrm{E}$ ). The two districts are characterized by crop-livestock mixed farming system where livestock in general and dairy production, in particular, contributes significantly to livelihoods of the smallholder farmers. Adaberga district is located $64 \mathrm{~km}$ west of Addis Ababa, capital city of Ethiopia. It is situated at an altitude ranging from 1,166 to $3,238 \mathrm{~m}$ above sea level and with an estimated area of 131 $\mathrm{km}$ square. The area receives on average an annual rainfall ranging from about 887 to 1,194 $\mathrm{mm}$. The average annual daily temperature of the area ranges from 11 to $21^{\circ} \mathrm{C}$. The population of Adaberga district is 120,654 based on the information from district agricultural office. Livestock production is an essential part of the farming system as nearly all land 
Creative Commons User License: CC BY-NC-ND

Abstracted by: EBSCOhost, Electronic Journals Service (EJS), Google Scholar, Journal Seek, Scientific Commons,

Food and Agricultural Organization (FAO), CABI and Scopus
Journal of Agricultural Extension

Vol. 24 (3) July, 2020

ISSN(e): 24086851; ISSN(Print); 1119944X

http://journal.aesonnigeria.org

http://www.ajol.info/index.php/jae

Email: editorinchief@aesonnigeria.org

preparation is done with ox-drawn plows. The district consists of 46,541 cattle, 57,511 sheep and 43,574 goats.

Cheliya district is also located in west Showa zone of Oromia state in Ethiopia. The area is located at $175 \mathrm{~km}$ west of Addis Ababa. It is situated at an altitudinal range of 1,700 to 3,060 $\mathrm{m}$ above sea level. The average annual daily temperature of the area ranges from 10 to $25^{\circ} \mathrm{C}$. The population of this district is 182,262 (CSA, 2012). The district possesses livestock population consisting of 124,713 cattle, 22,220 goats, 11,578 horses, 8,294 mules, 1,331 donkeys, 34,348 sheep, and 53,930 poultry.

The two districts were purposively selected based on access to training in dairy husbandry practice and density of livestock population. A cross-sectional survey was conducted and the data were collected from a total of 180 smallholder dairy farmers (90 from each district). Sixty of the selected smallholder dairy farmers (30 from each district) were trained intensively on animal husbandry practices (feed production and feeding, hygienic milk production, milk handling and processing, animal health and record keeping) by researchers at the Holeta Agricultural Research Center for two days in May 2016. Three development agents from each district attended the training for the purpose of assisting the trained dairy farmers on the application of the information obtained during the training and further follow up of their progress. The remaining 120 smallholder dairy farmers, the control group (60 from each district), were randomly selected based on ownership of lactating dairy cows from nearby villages that were not included in the training to avoid possible spillover effects likely to occur between farmers within the same village.

A semi-structured questionnaire was prepared and pre-tested to ensure necessary adjustments before the actual data were collected. A face to face interview was employed to collect the primary data from the selected 180 respondent dairy farmers. Both qualitative and quantitative data were collected. The information collected from the participants includes demographic (age of the household head, sex of the household head, educational status, family size) and socio-economic characteristics (experience in dairying, extension service obtained, veterinary service obtained, area of land allocated to forage production, access to credit, access to feed, access to market, milk (sold, consumed, processed, yield and income) and price of milk and milk products. The survey was conducted in March 2017, which was 10 months after the training provided.

Continuous and dummy variables and outcome indicators included in the PSM are defined in Table 1. 
Creative Commons User License: CC BY-NC-ND

Abstracted by: EBSCOhost, Electronic Journals Service (EJS), Google Scholar, Journal Seek, Scientific Commons,

Food and Agricultural Organization (FAO), CABI and Scopus
Journal of Agricultural Extension

Vol. 24 (3) July, 2020

ISSN(e): 24086851; ISSN(Print); 1119944X

http://journal.aesonnigeria.org

http://www.ajol.info/index.php/jae

Email: editorinchief@aesonnigeria.org

Table 1: Definition of variable and measurements used in the analysis

\begin{tabular}{|c|c|c|}
\hline Variables & Type ${ }^{1)}$ & Definition and measurement \\
\hline Age & C & Age of the household head in years \\
\hline Sex & D & 1 if male, 0 otherwise \\
\hline Marital status & D & 1 if the farm head is married, 0 otherwise \\
\hline Farmer education & D & 1 if attend formal school, 0 otherwise \\
\hline Family size & C & Number of household members \\
\hline Experience & C & Number of years involved in dairying \\
\hline Extension service & D & 1 if access to extension service, 0 otherwise \\
\hline Veterinary service & D & 1 if obtained veterinary services, 0 otherwise \\
\hline Market distance & C & Walking distance to the nearest market $(\mathrm{km})$ \\
\hline Cooperative & D & 1 if member of a cooperative, 0 otherwise \\
\hline Credit service & D & 1 if the farm get access to credit, 0 otherwise \\
\hline Training & D & 1 if trained, 0 otherwise \\
\hline Dairy cattle & C & Number of dairy cattle per farm \\
\hline Forage land & C & Forage land size per farm \\
\hline Annual milk income & C & $\begin{array}{l}\text { Milk income (deducting labor and concentrate } \\
\text { feed cost) in ETB2) }\end{array}$ \\
\hline Milk processed & C & Average daily milk processed by the $\mathrm{HH}$ in liters \\
\hline Milk productivity & C & Average daily milk yield/crossbred cow in liters \\
\hline
\end{tabular}

Note: ${ }^{1)} \mathrm{C}=$ continuous variable, $\mathrm{D}=$ dummy variable

2) $E T B=$ Ethiopian currency

The Propensity Score Matching (PSM) technique was used to test the general hypothesis that farmers who are trained on dairy husbandry practices could apply the knowledge to improve milk production per household and annual milk income. In the case of the non-experimental method, the presence of selection bias which arises due to differences in observable characteristics can be avoided by the use of PSM model. In this technique, participant dairy farmers, both trained (treated) and non-trained (control) groups are matched based on their observable characteristics.

To measure the average treatment effect on the treated (ATT) for the intended outcome variables, a logit model was used in order to get the propensity scores. PSM constructs a statistical comparison group that is based on a model of the probability of participating using observable characteristic. Then, based on the propensity score determined and matching estimator selected, matching between treatment and control group is done to find out the impact of training on the mean values of the outcome variables. The PSM technique is therefore used to control selection bias since it accounts between the outcomes of the treatment and control groups which provides an unbiased estimate by controlling observable factors and reduces matching problems (Taylor, 2018).

The choice of a matching estimator is a crucial aspect of implementing PSM. The matching method consists of trained and non-trained groups that are comparable in a large number of observable characteristics (Abadie and Imbens, 2016). The key assumption for the validity of the method is that the unobservable characteristics are sufficiently similar across the 
Creative Commons User License: CC BY-NC-ND

Abstracted by: EBSCOhost, Electronic Journals Service (EJS), Google Scholar, Journal Seek, Scientific Commons,

Food and Agricultural Organization (FAO), CABI and Scopus
Journal of Agricultural Extension

Vol. 24 (3) July, 2020

ISSN(e): 24086851; ISSN(Print); 1119944X

http://journal.aesonnigeria.org

http://www.ajol.info/index.php/iae

Email: editorinchief@aesonnigeria.org

trained and non-trained farmers before the training. In this study, the Kernel matching (KM) method was employed.

\section{Results and Discussion}

\section{Factors Influencing the Probability to be Included in Training}

Table 2 shows that experience in dairying $(z=2.58)$, area of land allocated to forage production $(z=2.5)$, veterinary services obtained $(z=2.29)$ and distance to the nearest market $(z=1.74)$ positively and significantly influenced the likelihood of dairy farmers' participation in the training program at 1\%,5\%,5\% and $10 \%$ level, respectively. On the other hand, farmers who had access to credit $(z=-1.65)$ and cooperative membership $(z=$ 2.38) have shown the negative and significant effect to participate in the training at $10 \%$ and $1 \%$ level, respectively. Factors such as the age, education status, number of lactating crossbred cows owned, sex of $\mathrm{HH}$ head, family size and extension service obtained were not significant in explaining the probability of being included in dairy husbandry training.

Estimates for the probability of being included in the dairy husbandry training indicates that participants who had more access to veterinary services had more chance to be included in the training, this may be associated to dairy farmers with more animal health problem referred for training. Participants who are far from market had also more chance to be included in the training. This is because dairy farmers who are near to market may have better access to information to increase the shelf life of their milk products than those who live far from market. Area of land allocated to forage production is also one of the most important predictors that has shown positive impact on milk income. This may be associated with the fact that dairy farmers with assets such as land allocated for forage production are willing to implement the skills and knowledge obtained from the training. On the other hand, cooperative membership and access to credit has shown negative response to training. Cooperatives are mandated to provide services such as training for members. Thus, during the selection of dairy farmers for training, agricultural experts give less chance for members of cooperatives assuming that members get information from their cooperatives. Similarly, studies indicated that poor farmers are marginalized from development interventions (Zaidi, 2012). 
Creative Commons User License: CC BY-NC-ND

Abstracted by: EBSCOhost, Electronic Journals Service (EJS), Google Scholar, Journal Seek, Scientific Commons,

Food and Agricultural Organization (FAO), CABI and Scopus
Journal of Agricultural Extension

Vol. 24 (3) July, 2020

ISSN(e): 24086851; ISSN(Print); 1119944X

http://journal.aesonnigeria.org

http://www.ajol.info/index.php/iae

Table 2: Estimates of participation in dairy husbandry training

\begin{tabular}{lrrr}
\hline Training & Coef. & \multicolumn{1}{c}{ SE } & \multicolumn{1}{c}{ Z } \\
\hline Sex & -0.33 & 0.46 & -0.72 \\
Age & -0.02 & 0.03 & -0.61 \\
Education & 0.11 & 0.45 & 0.24 \\
Experience & 0.08 & 0.03 & $2.58^{*}$ \\
EXS & 0.11 & 0.59 & 0.19 \\
Credit & -1.01 & 0.61 & $-1.65^{*}$ \\
Land for forage & & & \\
production & 1.16 & 46 & $2.5^{*}$ \\
COW & 0.001 & 0.3 & 0 \\
FAM & -0.08 & 0.83 & -0.9 \\
Vertirinary & 1.206 & 0.53 & $2.29^{*}$ \\
COOP & -1.909 & 0.801 & $-2.38^{*}$ \\
MKT & 0.376 & 0.216 & $1.74^{*}$ \\
Constant & -1.176 & 1.001 & -1.17 \\
\hline PSO.05 & & &
\end{tabular}

${ }^{*} \mathrm{P} \leq 0.05$

Pseudo $R^{2}=0.15$

Log likelihood $=-97.66$

Number of observations $=180$

Source: Field survey (2017)

\section{Treatment Effect of Training}

The average treatment effect on the treated of dairy husbandry training on annual milk income, milk production, sold, processed and consumed were computed based on estimates of propensity score and constructed outcome variables. Table 3 presents the ATT estimation based on KM methods. The difference between the average annual milk income (AMI) of trained and matched non-trained groups are between ETB 1,786 per year per $\mathrm{HH}$. This shows that the average incomes of the trained dairy farmers are significantly greater than the average income of non-trained dairy farmers. In agreement with our findings, study in India indicated that training increased net income per animal per year by Rs. 2607.82 (Sharma et al., 2014).

It can be inferred that any difference between the average incomes of the matched group is the outcome of their participation in dairy husbandry training practices based on the fact that the two groups are matched with the assumption of having equal propensity scores. Similarly, the difference in average daily milk productivity (MPD) was significantly higher at $1 \%$ level for trained dairy farmers. The volume of milk processed (MPC) was also significantly higher at $10 \%$ level after training. Our results show that dairy husbandry training has shown positive impact on annual milk income, milk production and volume of milk processed.

Estimates of the ATT with KM method shows that milk productivity (MPD) and volume of milk processed (MPC) by trained dairy farmers were higher by $21.7 \%$ and $56.5 \%$ than non-trained dairy farmers (Table 3 ). This is associated to attitudinal change due to the skill 
Creative Commons User License: CC BY-NC-ND

Abstracted by: EBSCOhost, Electronic Journals Service (EJS), Google Scholar, Journal Seek, Scientific Commons,

Food and Agricultural Organization (FAO), CABI and Scopus
Journal of Agricultural Extension

Vol. 24 (3) July, 2020

ISSN(e): 24086851; ISSN(Print); 1119944X

http://journal.aesonnigeria.org

http://www.ajol.info/index.php/jae

Email: editorinchief@aesonnigeria.org

and knowledge obtained from the training that enhanced trained dairy farmers to use more input and services (area of land allocated to forage production, amount of concentrated provision per cow per day, access to extension and veterinary services) than non-trained dairy farmers. This finding is consistent with the findings of Kazanga (2012), where farmers participating in training showed a highly significant change in milk yield after training. Also trained dairy farmers obtained $22.5 \%$ more income from milk (AMI) than the non-trained dairy farmers. In general, this study indicates that dairy husbandry training plays significant role in technology uptake and dissemination by smallholder dairy farmers in developing countries.

Table 3: Estimates of average treatment effect on selected indicators

\begin{tabular}{llrrrrrr}
\hline Variable & Sample & \multicolumn{1}{c}{ Treated } & Control & Difference & \multicolumn{1}{c}{ SE } & T-stat & \\
\hline Annual milk income & Unmatched & 10422.44 & 7705.87 & 2716.57 & 775.35 & 3.5 & \\
& ATT $(\mathrm{KM}, 0.1)$ & 9738.52 & 7952.49 & 1786.03 & 890.71 & 2.01 \\
Milk productivity & Unmatched & 6.58 & 5.21 & 1.37 & 0.18 & 7.55 & \\
& ATT $(\mathrm{KM}, 0.1)$ & 6.46 & 5.31 & 1.15 & 0.23 & 5.01 & $*$ \\
Milk processed & Unmatched & 1.77 & 0.92 & 0.85 & 0.26 & 3.31 & \\
& ATT $(\mathrm{KM}, 0.1)$ & 1.79 & 1.15 & 0.65 & 0.35 & 1.84 & * \\
& & & & & & &
\end{tabular}

${ }^{*} \mathrm{P} \leq 0.05$

Source: Field survey (2017)

\section{Conclusions and Recommendations}

Difference in awareness was observed among the participants in the use of input and services. The likelihood of participation in animal husbandry training was higher for farmers who allocated more land to forage production, more experience in dairying, distance to market and who obtained more veterinary service. Trained dairy farmers obtained higher milk production and annual milk income than non-trained dairy farmers. Milk processing provided better income than selling fresh milk. In general, this study confirms that training on dairy husbandry plays great role to bring change in dairy technology adoption which further enhance livelihood of smallholder farmers through income generation.

Access to training was observed to be very low due to limited financial support from the public sector, which implies that more emphasis should be given to provide sustainable and continuous support for strengthening smallholder dairy farmers in developing countries.

\section{References}

Abadie A. and Imbens G.W. (2016) Matching on the estimated propensity score, Econometrica, 84 (2), 781-807.

Central Statistical Agency (CSA). (2012). The Federal Democratic Republic of Ethiopia Central Statistical Agency Agricultural Sample Survey. Addis Ababa, Ethiopia.

Dehinenet G., Mekonnen H., Kidoido M., Ashenafi M. and Guerne B.E. (2014). Factors influencing adoption of dairy technology on small holder dairy farmers in selected zones of Amhara and Oromia National Regional States, Ethiopia. Discourse Journal of Agriculture and Food Sciences, 2(5), 126-135.

Dessisa, F., Roesel, K., Makita, K., Teklu, A., Zewde, G. and Grace, D. (2015). Food safety and informal markets, In Roesel K and Grace D (eds.) Is raw milk safe for human consumption in Ethiopia? (pp.135-139), London, UK, Routledge. 
Creative Commons User License: CC BY-NC-ND

Abstracted by: EBSCOhost, Electronic Journals Service (EJS), Google Scholar, Journal Seek, Scientific Commons,

Food and Agricultural Organization (FAO), CABI and Scopus
Journal of Agricultural Extension

Vol. 24 (3) July, 2020

ISSN(e): 24086851; ISSN(Print); 1119944X

http://journal.aesonnigeria.org

http://www.ajol.info/index.php/iae

Email: editorinchief@aesonnigeria.org

Guadu T. and Abebaw M. (2016). Challenges, Opportunities and prospects of dairy farming in Ethiopia: A Review. World Journal of Dairy \& Food Sciences 11 (1), 1-9.

Kazanga, D.T. (2012). The impact of dairy management training of small scale dairy farmers on milk yield and quality in Malawi. Master's Thesis, University of Florida, USA.

Luyombya, B.G.P. (2014). Farmers training and its influence on adoption of improved dairy husbandry practices in Arumeru district, Tanzania. Master thesis, Sokoine University of Agriculture, Tanzania.

Samuel, D.C., Misganaw, A.T., Efrem, A.G., Beza E.E., Addisu, B. A. (2016). Adoption and Impacts of Dairy Production Technologies in Southwest Ethiopia: The Cases of Jimma and llu-Ababora Zones. Journal of Biology, Agriculture and Healthcare, 6(7).

Sanjeev M.V, Singha A.K., and Venkatasubramanian V. (2012). Training needs of farmers and rural youth: an analysis of Manipur State, India. Journal of Agricultural Sciences, 3(2),103-112.

Sharma, M. Singh, G. and Keshava. (2014). Impact evaluation of training programs on dairy farming in Punjab state, India. Indian Research Journal of Extension Education,14(1),105-108.

Taylor J.E. (2018). Agricultural development impact evaluation, In G. L. Cramer, K.P. Paudel, \& A. Schmitz (Eds.), The Routledge Handbook of Agricultural Economics (pp 548-580). London, UK, Routledge.

Ullah S. (2016). Efficiency measurement of dairy farmers under integrated cropping systems in Pakistan. PhD thesis, Georg-August-University Göttingen, Germany

United Nations, (2015). Department of Economic and Social Affairs, Population Division. World Population Prospects: The 2015 Revision, Key Findings and Advance Tables. Working Paper No. ESA/P/WP. 241.

Wordofa M.G. and Sassi M. (2018). Impact of farmers' training centers on household income: evidence from propensity score matching in Eastern Ethiopia. Social Sciences, 7(4).

Zaidi, S.A. (2012). The captivating vision of the "New growth strategy": The missing political economy perspective, Lahore Journal of Economics, 17, 33-49. 